\title{
Post-rift vertical movements and horizontal deformations in the eastern margin of the Central Atlantic: Middle Jurassic to Early Cretaceous evolution of Morocco
}

\author{
Giovanni Bertotti · Mohamed Gouiza
}

Received: 25 June 2011/Accepted: 31 March 2012/Published online: 27 April 2012

(C) The Author(s) 2012. This article is published with open access at Springerlink.com

\begin{abstract}
Wide regions of Morocco, from the Meseta to the High Atlas, have experienced km-scale upward vertical movements during Middle Jurassic to Early Cretaceous times following the appearance of oceanic crust in the Central Atlantic. The area experiencing exhumation was flanked to the $\mathrm{W}$ by a domain of continuous subsidence, part of which is named the Essaouira-Agadir basin. Comparison with vertical movement curves predicted by lithospheric thinning models shows that only $50-60 \%$ of the subsidence documented in the Essaouira basin can be explained by postrift thermal relaxation and that $<30-40 \%$ of the observed exhumation can be explained by processes (in)directly related to the evolution of the Central Atlantic rifted margin. Syn-sedimentary structures in Middle Jurassic to Lower Cretaceous formations of the Eassouira-Agadir basin are common and range from $\mathrm{m}$-scale folds and thrusts to $\mathrm{km}$-scale sedimentary wedges. These structures systematically document coeval shortening generally oriented at high
\end{abstract}

\author{
G. Bertotti $(\bowtie)$ \\ Department of Geoscience and Engineering, Delft University \\ of Technology, Stevinweg 1, 2628 CN Delft, The Netherlands \\ e-mail: g.bertotti@tudelft.nl \\ G. Bertotti · M. Gouiza \\ Department of Tectonics and Structural Geology, \\ VU University Amsterdam, De Boelelaan 1085, \\ 1081 HV Amsterdam, The Netherlands \\ e-mail:mgouiza@mun.ca \\ M. Gouiza \\ Netherlands Research Centre for Integrated Solid Earth Science \\ (ISES), Amsterdam, The Netherlands \\ Present Address: \\ M. Gouiza \\ Department of Earth Sciences, Memorial University \\ Newfoundland, St. John's, Canada
}

angle to the present margin. As a working hypothesis, it is suggested that regional shortening can explain the structural observations and the enigmatic vertical movements.

Keywords Post-rift uplift - Post-rift deformation . Passive margin $\cdot$ Morocco $\cdot$ Essaouira basin

\section{Introduction}

The recent discovery of Late Triassic to Early Cretaceous $\mathrm{km}$-scale vertical movements, subsidence and then exhumation, affecting substantial parts of Morocco which had hitherto been considered as stable (Ghorbal et al. 2008; Saddiqi et al. 2009; Barbero et al. 2011; Ruiz et al. 2011) represents a major development in Moroccan geology, opening new horizons for understanding the Mesozoic tectonic evolution of NW Africa. The exhumation component of these movements, in particular, is remarkable as it took place after the appearance of oceanic crust in the Central Atlantic, that is, during its passive margin development (e.g., Sahabi et al. 2004; Gouiza et al. 2010). Exhumation is clearly older than, and therefore, unrelated to Alpine contraction in the two orogens of NW Africa, namely the Rif and the Atlas. Upward movements are unusual during the drifting stage, but our discoveries are part of an increasing awareness that passive margins could be less passive than believed hitherto (e.g., Bache et al. 2011; Japsen et al. 2009).

In the recent past, a number of studies by different groups (e.g., Ghorbal et al. 2008; Saddiqi et al. 2009; Ghorbal 2009; Barbero et al. 2011; Ruiz et al. 2011) have concluded that rocks of the Meseta of N Morocco, the High Atlas and parts of the Anti-Atlas, have experienced $>1 \mathrm{~km}$ of exhumation during Middle Jurassic to Early Cretaceous 
times. More low-temperature geochronology (low-T) work is ongoing on samples from the Anti-Atlas and areas of southern Morocco (Bertotti et al. 2010) and will undoubtedly result in new relevant information. The focus of the present study is on the tectonic regime driving the observed vertical movements. To reach this goal, we compile data on vertical movements along a roughly $\mathrm{W}-\mathrm{E}$ trending, $\sim 100$-km-long section connecting areas of strong Jurassic to Early Cretaceous subsidence, the Essaouira-Agadir basin, with domains of strong coeval exhumation, the Massif Ancien de Marrakech (MAM) (Fig. 1). We compare these estimates with values predicted by numerical models of rifted margin evolution and conclude that a significant portion of such movements cannot be explained by current models. To constrain the nature of the tectonics driving these enigmatic vertical movements, we identify and interpret syn-tectonic deformation structures in the Mesozoic sediments of the Essaouira-Agadir basin cropping out to the $\mathrm{W}$ of the area experiencing Jurassic to Early Cretaceous exhumation. Finally, we integrate horizontal deformations and vertical movements to propose a tentative kinematic reconstruction for the Jurassic to Cretaceous evolution of the section from the Moroccan onshore in the Essaouira-Agadir basin region to the central part of the High Atlas.

\section{The geological framework}

The main domains

The present-day geology of northern Morocco (Fig. 1) is characterized by two orogenic belts of Tertiary age, the Rif

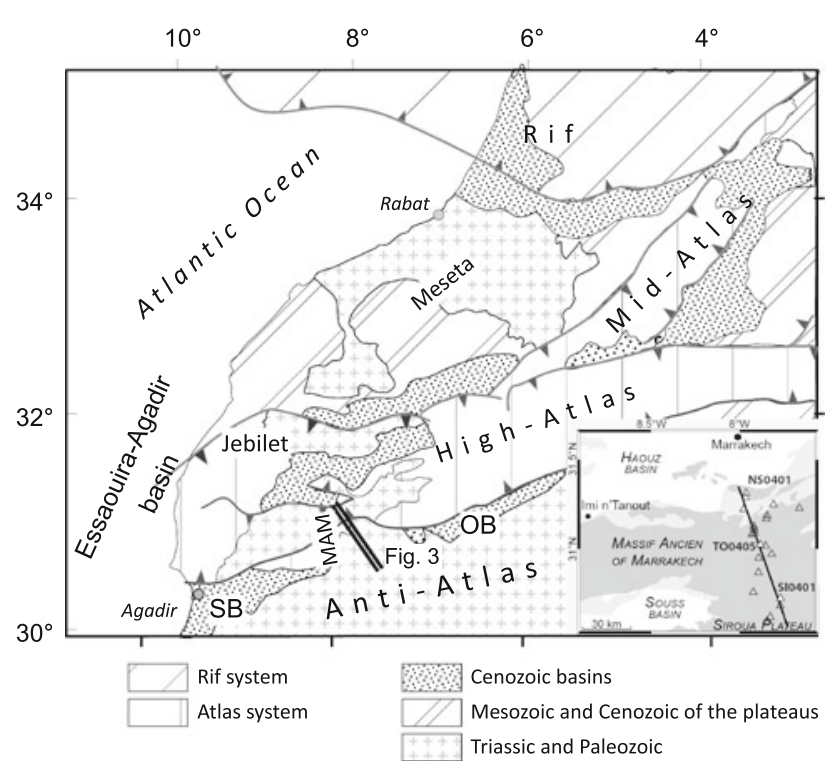

Fig. 1 Schematic geological map of Morocco (simplified from Hafid et al. 2006). $O B$ Ouarzazate basin; $S B$ Souss basin; $M A M$ massif ancien de marrakech. The inset shows the detailed trace of Fig. 3 and the position of the investigated samples
Mountains in the $\mathrm{N}$ and the Atlas Mountains in the $\mathrm{S}$ and $\mathrm{E}$, both developed in association with the convergence between Europe and Africa. The area between the two orogens is the Moroccan Meseta. The Rif mountains, a mainly thin-skinned fold-and-thrust belt incorporating parts of the European and African passive margins and of the intervening oceanic crust (e.g., Chalouan et al. 2001), is not of significant interest to our study and will not be further considered.

Mesozoic sediments, recording phenomena taking place during the time span of interest to this contribution, are mainly found along the Central Atlantic and the High Atlas inverted rift systems, which developed in association with the opening of the Central Atlantic and Tethyan Oceans. The Mesozoic succession in the Meseta and other non-orogenic areas is much more discontinuous and typically characterized by a major unconformity separating Upper Cretaceous marine limestones from metamorphosed Hercynian basement.

\section{The Meseta}

The Meseta is a fairly flat-lying domain characterized by a Hercynian basement (e.g., Hoepffner et al. 2005; Michard et al. 2008) overlain by scattered Triassic continental sediments and extensive Upper Cretaceous shallow marine carbonates. The upper boundary of the Paleozoic basement at the contact with non-metamorphic sediments shows little palaeo-topography suggesting that the Hercynian orogen had been effectively peneplained prior to Mesozoic sedimentation (e.g., Michard 1976; Hoepffner et al. 2005). Triassic syn-rift structures, generally oriented N-S, host limited thicknesses of mainly terrigenous sediments.

The stratigraphic gap characterizing the central Meseta decreases toward the $\mathrm{W}$, and in the offshore, the sedimentary succession is essentially continuous having experienced persisting subsidence throughout the syn- and post-rift stages of Central Atlantic opening (e.g., Hafid et al. 2008; Gouiza et al. 2010).

\section{The Atlas system}

The Atlas orogen begins in the W, offshore EssaouiraAgadir (e.g., Hafid et al. 2006) and continues onshore in ENE direction traversing Morocco, Algeria, and reaching eventually Tunisia (Frizon de Lamotte et al. 2000). The Atlas fold-and-thrust belt originates from the Eocene to Pliocene inversion of a Triassic-Jurassic graben system developed during the opening of the Central Atlantic and, somewhat later, of the Tethyan ocean in the NE. Northeast of Marrakech, the Middle Atlas splits away from the High Atlas and joins the Rif in NE Morocco (Fig. 1). Shortening has been estimated at $<25 \%$ accommodated by predominantly thick-skinned thrusts (e.g., Teixell et al. 2003; Arboleya et al. 2004). 
The High Atlas is traditionally subdivided into a western and a central part separated by a large area of crystalline basement cropping out south of Marrakech known as the MAM (Michard 1976) (itself part of the West Moroccan Arc) (Fig. 1). The MAM is generally interpreted as a morphologic high resulting from the Hercynian orogeny that separates the two segments of the High Atlas from the Triassic to Present (e.g., Michard 1976). This interpretation was contested by German authors (e.g., Stets 1992) and has been recently disproven by low-T geochronology (see below).

\section{The areas to the $S$ of the High Atlas}

Geographically, the High Atlas passes toward the $S$ to the Anti-Atlas with the partial interposition of two shallow foredeep basins, the Sous basin in the west and the Ouarzazate basin in the east (Fig. 1). The two basins are separated by the Siroua plateau, which lies on the southern continuation of the MAM and forms a morphologic link between the High Atlas and the Anti-Atlas.

The Anti-Atlas is a high mountain belt with summits reaching elevations of $>3,300 \mathrm{~m}$. The rough and high topography are at odds with the generally assumed very old age of its dominant deformation and its subsequent stable character (e.g., Stets and Wurster 1982). Brittle deformation is ubiquitous but commonly attributed to (late) Hercynian episodes (e.g., Burkhard et al. 2006; CerrinaFeroni et al. 2010). An Alpine age for at least part of the deformations has been proposed by Malusà et al. (2007) and Guimera et al. (2011). Unfortunately, dating is difficult because of the scarcity of Mesozoic to Tertiary sediments.

\section{Kinematics of the NW Morocco rifted margin}

The opening of the Central Atlantic and related basins was the most important process affecting Morocco during Triassic to Early Cretaceous times. Despite the substantial amount of studies dedicated to the topic, the ages of the onset and end of rifting are debated (e.g., Sahabi et al. 2004; Gouiza et al. 2010; Labails et al. 2010) and there exist only very few estimates on the amount of extension experienced by the margin through time.

In accordance with most studies, we assume that riftrelated normal faulting began in Carnian times at $\sim 225$ Ma (e.g., Laville et al. 2004) and created two main extensional systems: a NNE-SSW trending one which led eventually to opening of the Central Atlantic and an ENEWSW striking system, the Atlas rift, which was abandoned during the Early Jurassic. While normal faults in the Central Atlantic system are generally well imaged in seismic lines, this is less the case for extensional faults in the Atlas because of their subsequent reactivation during
Tertiary contraction. Most normal faults were steep accommodating a total extension of $<10 \%$ (e.g., Gouiza et al. 2010). The Central Atlantic and Atlas systems come together in the area of the Essaouira-Agadir basin where faults of the two trends are encountered and where strong subsidence took place allowing for the deposition of a several kilometers thick Mesozoic sedimentary succession (e.g., Medina 1995; Hafid et al. 2008).

There is a general agreement that normal faulting ended before the late Liassic, at $\sim 196 \mathrm{Ma}$ (e.g., Hafid et al. 2008). This is well documented in seismic lines in the Essaouira basin and in the Central Atlantic margin. Depending on the interpretations, cessation of normal faulting coincides with or it is significantly older than the first appearance of oceanic crust in the Central Atlantic (Sahabi et al. 2004; Davison 2005, respectively). In our study, we will follow the traditional approach assuming an age of $175 \mathrm{Ma}$ for break-up.

\section{Vertical movements and passive margin evolution}

In this section, we compile data on Mesozoic vertical movements along a $\sim 100$-km-long transect along the western part of the High Atlas from the Essaouira-Agadir basin in the $\mathrm{W}$ to the MAM in the East. We focus especially on the areas experiencing upward movements as the sedimentary record documenting subsidence have been extensively described in the literature (e.g., Hafid et al. 2008; Hafid et al. 2006; Zühlke et al. 2004; Le Roy and Piqué 2001; Bouatmani et al. 2007; Ellouz et al. 2003). These movements (Fig. 2) are then compared with those predicted by rifting models.

\section{Observed movements}

\section{Upward movements in the MAM}

A significant amount of low-T geochronological studies has been performed in the High Atlas during the last years (Missenard et al. 2008; Balestrieri et al. 2009; Ghorbal 2009). Because of the lithological limitations imposed by the Apatite Fission Track and (U-Th)/He methods, practically all samples measured by the different authors originate from the MAM and, more specifically, from the Paleozoic basement and its stratigraphic cover of Triassic continental deposits. The most complete data set has been presented in a $\mathrm{PhD}$ Thesis carried out at the VU University Amsterdam to which we refer for specific information (Ghorbal 2009). Samples have been taken from the northern foothills, the central domain around Jebel Toubkal and, further to the $\mathrm{S}$, from the Siroua plateau (see inset in Fig. 1). 
Fig. 2 The sediments of the Essaouira-Agadir basin. a Schematic stratigraphic column (simplified from Hafid et al. 2008); b subsidence curves from 3 selected localities in the onshore portion of the Essaouira basin (from Bouatmani et al. 2007); position is indicated in Fig. 5 (a)

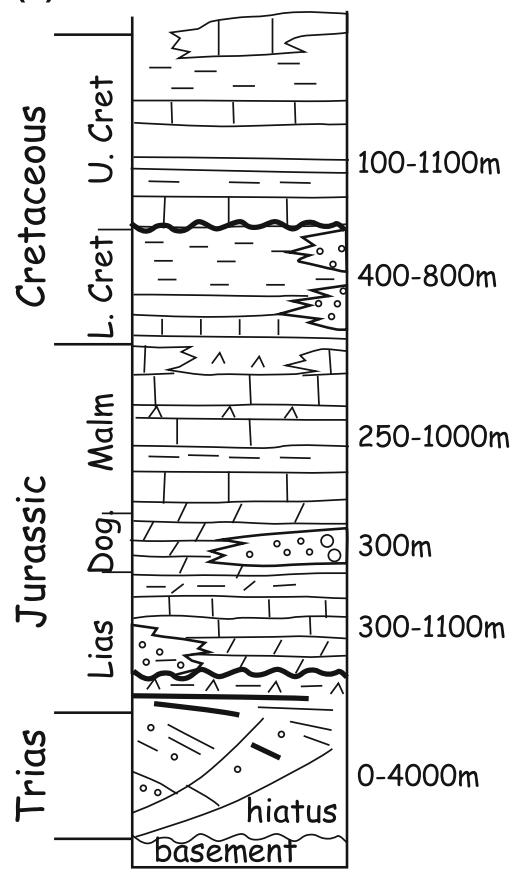

(b)

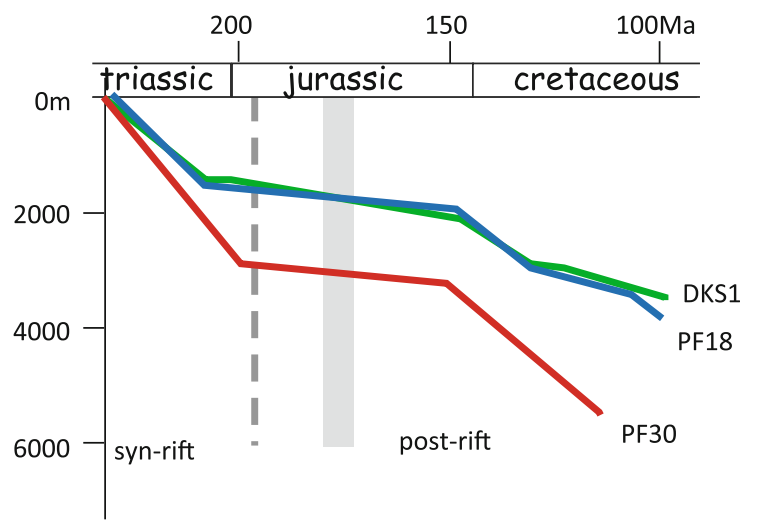

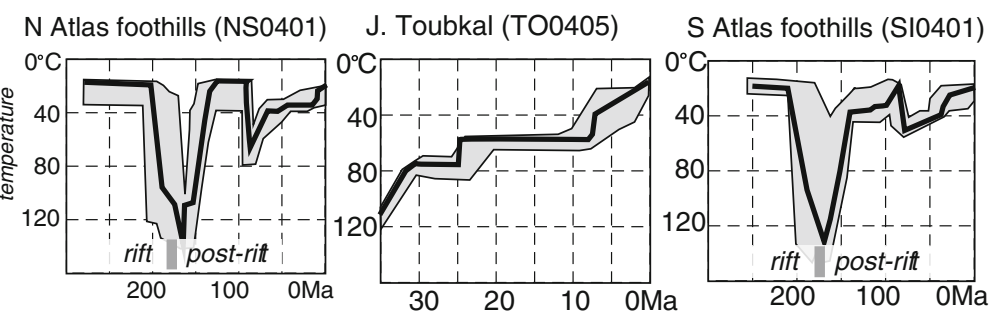

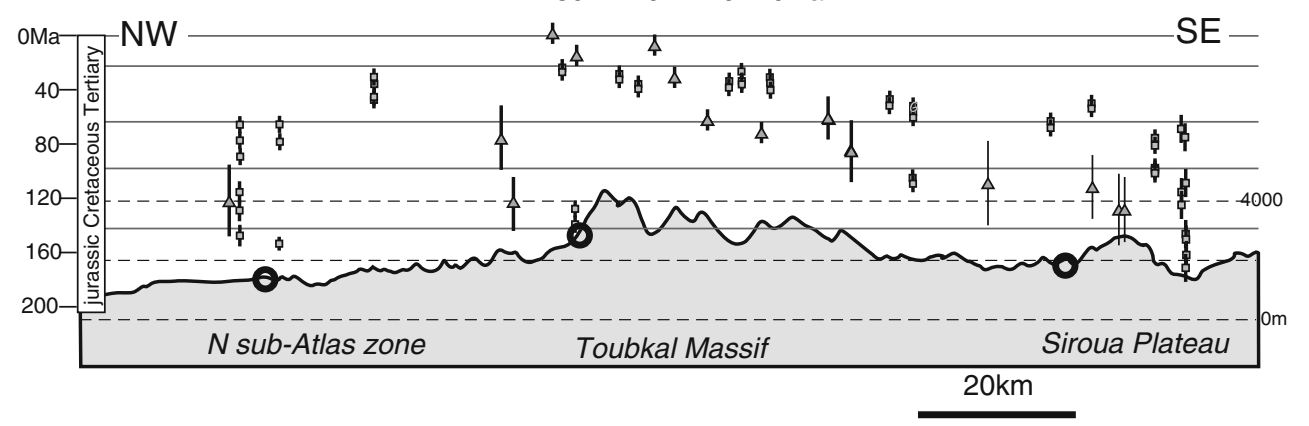

Fig. 3 Low-T geochronology data from a transect across the High Atlas (see inset in Fig. 1 for location of transect). Lower panel topographic profile with apatite fission track (triangles) and (U-Th)/

Apatite Fission Track and (U-Th)/He ages from all samples are Jurassic to Tertiary (Ghorbal 2009) (Fig. 3). Similarly to the Meseta, no Hercynian ages were found. Jurassic to Cretaceous fission track ages have been obtained from the northern and southern foothills of the High Atlas (Fig. 3). Tertiary ages are only found in the axial part of the mountain belt. The obtained values are systematically younger than the deposition of the sediments and the metamorphism affecting the rocks from which the apatites
He ages (squares). Upper panel time-Temperature curves for samples from the $\mathrm{N}$ Foothills, the axial domain and the Siroua Plateau. Modified and simplified from Ghorbal (2009)

have been obtained. This implies that, following deposition, these sandstones and the stratigraphically underlying basement have been buried to depths where temperatures were high enough to cause full annealing of the apatite fission tracks and then moved upward experiencing cooling. Samples with Tertiary ages were exhumed only during the Atlas orogeny and bear no memory of their Mesozoic vertical movements (see Toubkal time-temperature path in the upper panel of Fig. 3). 
Time-temperature paths from representative samples from the northern foothills and the Siroua plateau are shown in the upper panel of Fig. 3. The geological conditions that have been imposed on the modeling study are that the samples were close to the surface at the end of the Hercynian orogeny and immediately prior to the Late Cretaceous when they were covered by Upper Cretaceous marine carbonates. The t-T paths show that the samples started subsiding in Late Triassic times probably in association with continental rifting and reached a depth of $>3 \mathrm{~km}$ where temperatures were high enough to cause annealing of the apatite fission track system. At 170-150 Ma, the same rocks started moving upward and reached the surface prior to $100 \mathrm{Ma}$. For these samples, as well as all other samples described by Ghorbal (2009), exhumation took place during the drifting stage of Central Atlantic evolution.

\section{Downward movements in the Essaouira-Agadir basin}

In a very schematic fashion, the Mesozoic sedimentary succession of the Essaouira-Agadir basin is characterized by an up to 8-km-thick sedimentary succession separated in a syn-rift and a post-rift part by an angular unconformity of Toarcian age, interpreted as the break-up unconformity associated with the opening of the Central Atlantic (Medina 1995) (Fig. 2a). The post-rift Jurassic to Cretaceous succession is up to $4 \mathrm{~km}$ thick and mainly composed of shallow water carbonates with episodes of continental sedimentation during the Middle Jurassic to Early Cretaceous (e.g., Hafid et al. 2008 and references therein).

Three of the numerous subsidence curves that have been proposed for different localities in the onshore part of the Essaouira-Agadir basin are shown in Fig. 2b. They describe vertical movements of Triassic rocks in the proximal, central and distal part of the Essaouira basin. These curves show a decrease in subsidence rates around ca. 200 Ma coinciding with the local termination of normal faulting. Subsidence however continues and even accelerates after $150 \mathrm{Ma}$.

\section{Comparison with model predictions}

In previous sections, we have shown that the early passive margin evolution of the Moroccan margin of the Central Atlantic was characterized by the coexistence of subsidence in the W (Essaouira-Agadir basin) and exhumation in the $\mathrm{E}$ (MAM). The question we address here is whether the sign and magnitude of these vertical movements can be explained by passive margin development.

\section{Upward moving domain}

The km-scale exhumation documented for the MAM is at odds with classical, McKenzie-type models of rifted margins evolution which predict gentle post-rift subsidence driven by lithospheric cooling (McKenzie 1978). In more recent years, dynamic models of post-rift margin development have highlighted the importance of processes such shoulder uplift, erosion-driven crustal flow (Burov and Cloetingh 1997) and mantle-seated processes of convection and magmatism (e.g., Steckler 1985; Lucazeau et al. 2008). These models typically predict localized uplift but provide little information about the movement of physical particles (geological bodies) and the associated exhumation and erosion, thereby making difficult a comparison with realworld cases. In an extensive study on the evolution of the Central Atlantic margins of Morocco and Canada, Gouiza et al. (2009) and Gouiza (2011) considered the effect of secondary convection cells but were unable to predict an uplift/exhumation comparable to what observed in the transect of interest. Even in the most optimistic case, the authors could attribute to secondary convection only an exhumation of few hundred meters that is an order of magnitude less than what observed. In addition, the wavelength of the predicted exhumation was significantly larger than the observed one. We conclude that a significant portion $(>60 \%)$ of the observed upward vertical movements cannot be explained by rift- or post-rift-related processes.

\section{The downward moving domain}

To quantify and interpret the origin of the subsidence in Essaouira basin, we compare the backstripped subsidence curves shown in Fig. 2 with modeled curves predicted for different crustal thinning factors. The predicted curves have been obtained using 2D numerical modeling of a lithospheric extension (Kooi 1991; Kooi et al. 1992; Gouiza et al. 2010), which initiated in the Late Triassic ( 228 Ma) and ended in the Early Jurassic ( 196 Ma) when normal faulting ceased in most rift basins. The models assume uniform crustal and subcrustal thinning during rifting and a flexural lithosphere characterized by (1) an effective elastic thickness defined by the $450{ }^{\circ} \mathrm{C}$ isotherm, and (2) a 15-km-deep level of necking (i.e., similar to the lithospheric strength used by Gouiza et al. (2010) in the Doukkala margin to the N).

Inspection of Fig. 4 shows that initially, between 228 and 170-160 Ma, the subsidence in Essaouira basin is in agreement with the models as the observed curves follow relatively well the ones predicted for thinning factors between 1.2 and 1.5. Although no quantitative analysis exists, these values seem to require an extension significantly larger than what documented in the Essaouira basin. In the Doukkala basin, to the North of the Essaouira basin, Gouiza et al. (2010) did perform such an analysis and concluded that the observed extension translated in thinning factors $<1.2$. 


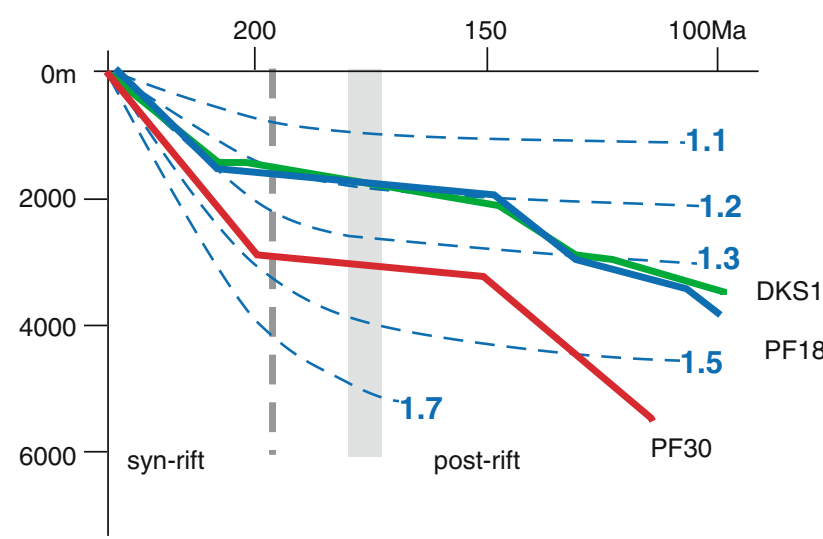

Fig. 4 Comparison between observed and predicted subsidence curves in the Essaouira basin. Observed subsidence curves are from Fig. 2. Assumptions made for predicted subsidence curves are described in text. The vertical grey dashed lines marks the end of normal faulting; the thick grey bar the appearance of oceanic crust in the Central Atlantic

In accordance with classical models, subsidence rates are high during normal faulting and decrease after the cessation of extension (dashed grey line in Fig. 4). No significant change is observed at $175 \mathrm{Ma}$ when the first oceanic crust appeared in the Central Atlantic. At 160-150 Ma, however, the subsidence curves display substantial deviation from predicted ones indicating renewed subsidence. During a time span of 40-50 Myr, rocks moved downward by an amount comparable to that experienced during rifting. The timing of renewed subsidence coincides with the onset of upward movements in the MAM and surrounding regions. The interpretation that the subsidence observed in the Essaouira basin could not be entirely explained by thermal relaxation had already been made by Piqué et al. (1998) but associated with regional transtension.

We conclude that realistic thinning models can only explain less than $50 \%$ of the observed post-rift subsidence. The remaining part $(1-2 \mathrm{~km})$ must be driven by different tectonic processes. This is a conservative estimate as the modeling curves have been obtained assuming a moderate strength of the underlying lithosphere.

Linking upward and downward moving domains: the Imi-n-Tanout wedge

The region to the SW of Imi-n-Tanout (Figs. 5, 6) is of particular interest because of the map-view wedge formed by Triassic to Lower Cretaceous sediments. The wedge links the MAM in the $\mathrm{E}$ with the Essaouira-Agadir basin in the $\mathrm{W}$ thereby providing relevant information on the kinematics of coeval upward and downward vertical movements (e.g., Stets 1992). In contrast to other regions, no evaporites are documented in the area and differential vertical movements must have a tectonic origin rather than being driven by halokinesis.

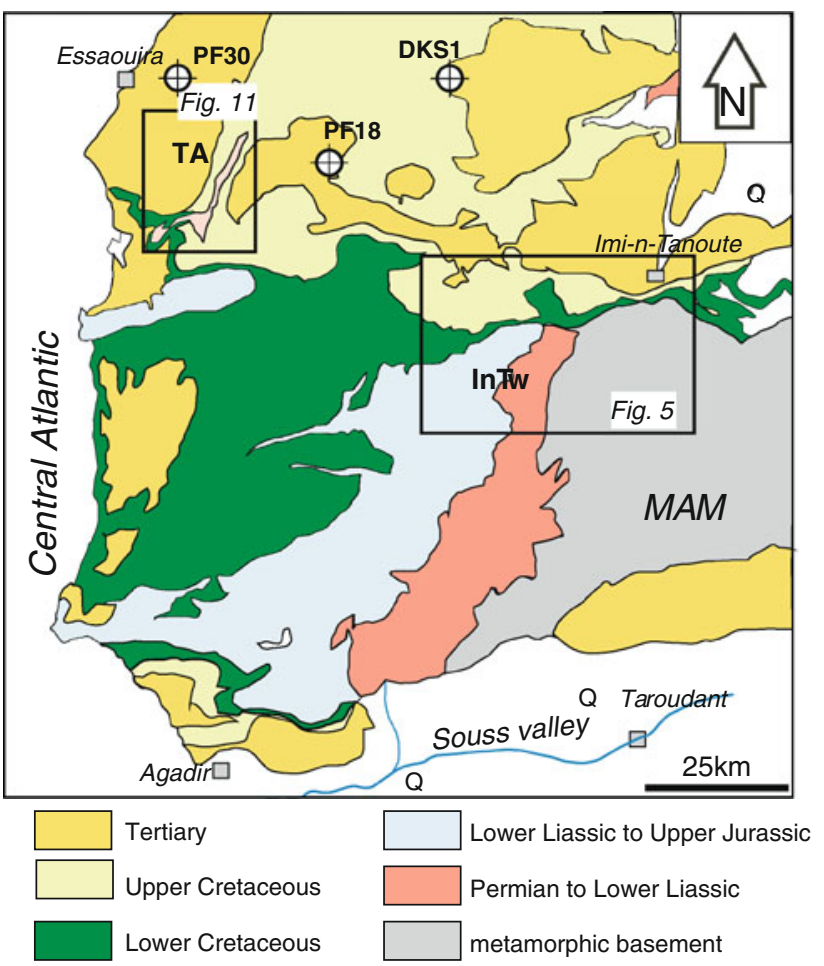

Fig. 5 Schematic geological map of the area between the MAM and the onshore part of the Essaouira basin (simplified from the sheet Marrakech of the 1:500,000 geological map of Morocco). TA Tidsi anticline, InTw Imi-n-Tanout wedge. The position of (synthetic) DKS1, PF18 and PF30 wells used for subsidence analysis (Fig. 4) is also shown. Names of wells are from Bouatmani et al. (2007)

\section{The wedge geometry}

In the eastern part of the area (Figs. 5, 6), Hercynian basement is unconformably overlain by Upper Permian to Lower Cretaceous sediments which typically show strikes changing from $\mathrm{N}-\mathrm{S}$ to $\mathrm{E}-\mathrm{W}$ moving up-section thereby forming a clear fan opening from $\mathrm{NE}$ to $\mathrm{SW}$. The Upper Permian to Lower Cretaceous succession is divided in two parts by the Toarcian unconformity, a regional erosional surface gently cutting down-section from SW to NE generally interpreted as the breakup unconformity which formed when oceanic crust appeared in the Central Atlantic (e.g., Medina 1995).

Upper Permian to Liassic sediments are mainly red beds with intercalations of volcanic rocks of the Central Atlantic Magmatic Province (Verati et al. 2007) beautifully exposed along the Argana valley (Fig. 5) (e.g., Medina 1995; Baudon et al. 2009). Upper Permian to Liassic sediments pinch-out between Upper Cretaceous and basement rocks to the W of Imi-n-Tanout (Figs. 5, 6) and thicken to the SW reaching $>6,000 \mathrm{~m}$ (Zühlke et al. 2004). The thickness changes are interpreted as associated with (1) a roughly N$\mathrm{S}$ trending, E-dipping normal fault supposedly located to the W of the Argana valley (e.g., Fig. 2 of Medina (1995)) 
and (2) the Toarcian unconformity, which descends downsection to the NE (e.g., Medina 1995).

A wedge geometrically similar to the one just described is formed by the post-rift part of the succession, that is, by Middle Jurassic to Lower Cretaceous sediments which overly the break-up unconformity (e.g., Stets 1992). These sediments show a fan geometry with dips to the NW in the $\mathrm{S}$, becoming northward in the N (Figs. 5, 6). The corresponding formations are basically continuous over the entire area and show a pattern of decreasing thicknesses from the SW to the NE (Stets 1992; Zühlke et al. 2004).

\section{The Imi-n-Tanout wedge in Cretaceous times}

The geometry of the post-rift portion of the Imi-n-Tanout wedge prior to Alpine shortening can be reconstructed using thickness measurements available from the literature (e.g., Zühlke et al. 2004; Bouaouda 2004) integrated with our own geological sections. Thicknesses for basically all post-rift formations increase gradually from NE to SW reaching $>3,000 \mathrm{~m}$ toward the coastal areas (Fig. 7). Subsidence rates seem to be very high during the Late Jurassic. No fault is inferred along the section which could provide a significant contribution to the observed thickness changes (Hafid et al. 2008).

The direction of the profile of Fig. 7 is conditioned by the present outcrops distribution along and in the neighborhood of the Argana valley. We derive the original trend of the wedge by plotting strikes and dips of Middle Jurassic to Lower Cretaceous layers and compensating for Alpine deformation. The result (Fig. 8) shows that the Imi-nTanout wedge opened along a NNW-SSE to NW-SE trending axis. This axis must have roughly corresponded to the trend of boundary between the subsiding area in the $\mathrm{W}$ and the exhuming domain in the E. The NNW-SSE direction is significantly oblique with respect to the NESW general trend of older, Middle Triassic to Early Jurassic syn-rift faults mapped or inferred in the Argana

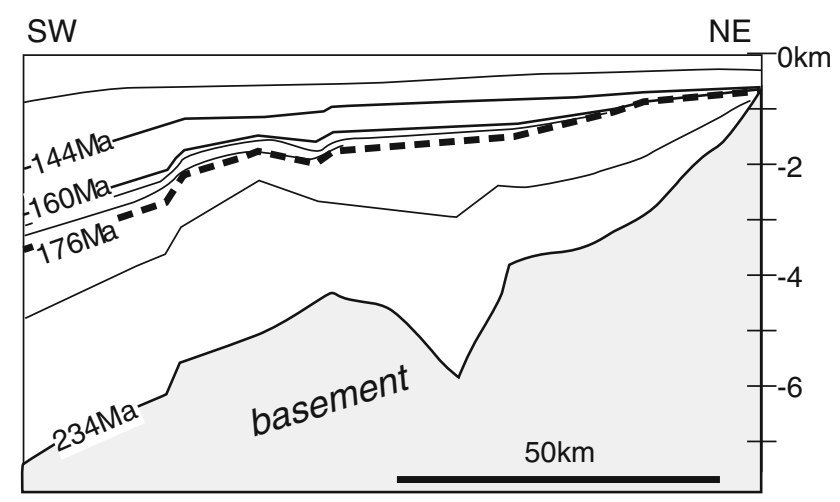

Fig. 7 The Imi-n-Tanout wedge at the end of the Early Cretaceous. Greatly simplified from Zühlke et al. (2004). The thick dashed line corresponds to the syn- to post-rift transition

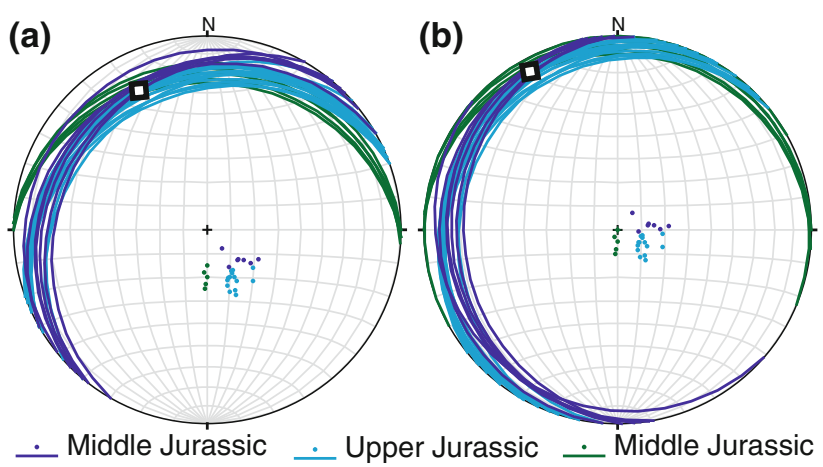

Fig. 8 Geometry of the Imi-n-Tanout wedge. a Present-day position of sedimentary layers; $\mathbf{b}$ position of the same layers prior to Alpine folding. Poles have been rotated in a counter-clockwise sense looking $\mathrm{W}$, around a $\mathrm{E}-\mathrm{W}$ trending axis by $15^{\circ}$
Fig. 6 Geological map of the NE part of the Imi-n-Tanout wedge. Simplified from sheet Marrakech of the 1:500,000 geological map of Morocco

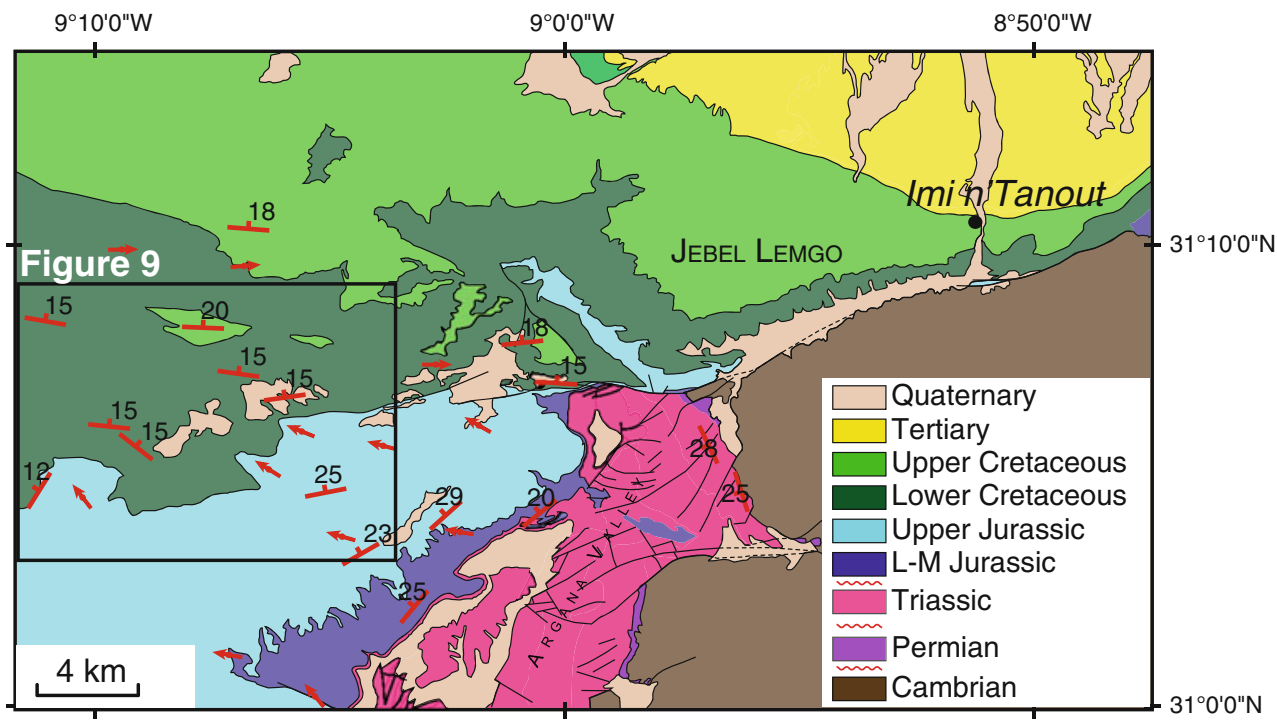


area (e.g., Medina 1995; Hafid 2000) discarding a possible reactivation (inversion) of Triassic to Early Jurassic normal faults as a mechanism contributing to Middle Jurassic to Early Cretaceous vertical movements.

\section{Syn-sedimentary deformations in the Essaouira basin}

To constrain the tectonics driving the Middle Jurassic to Early Cretaceous upward and downward vertical movements, which cannot be explained by models of rifted margins, we have investigated structures cropping out in the Essaouira-Agadir basin, which is the subsiding domain flanking the region experiencing exhumation (Fig. 5). Jurassic to Cretaceous sediments are present in these areas, and syn-sedimentary deformations can be identified and interpreted. Jurassic and Cretaceous anticlines have been described but their growth generally associated with diapirism rather than with regional tectonics (e.g., Hafid 2000).

\section{Imi-n-Tanout}

Middle Jurassic to Lower Cretaceous sediments to the South of the Imi-n-Tanout line are deformed by syn-sedimentary structures documenting the style of deformation during this times span. At the $\mathrm{km}$-scale, fairly symmetric, NW-SE trending folds are observed in the northern part of the wedge, which are sealed by Lower Cretaceous strata (Fig. 9). At a smaller, meters to tens of meters scale, syn- sedimentary structures are not uncommon in the Imi-nTanout wedge and typically show folds and thrusts with a NW-SE trending axis (Fig. 10). All these structures document Late Jurassic to Early Cretaceous NE-SW shortening approximately perpendicular to the axis of the Imi-nTanout wedge (see Sect. "The Imi-n-Tanout wedge in Cretaceous times"), suggesting that they developed within the same deformation regime.

Tidsi

The Tidsi anticline (Figs. 1, 11), exposed in the western High Atlas ca. $20 \mathrm{~km}$ east of the Atlantic coast, is a complex structure characterized by a main fold trending NNE-SSW, which interferes in the south with a shorter E-W to WSW-ENE trending anticline. The regional stratigraphy, the geometry of the fold and its predominantly Mesozoic age have been documented in previous studies (e.g., Amrhar 1995; Piqué et al. 1998; Hafid 2000) and interpreted as driven by halokinesis. No evaporites crop out in the Tidsi anticline, but a diapir-like body is imaged in seismic lines across the area (Hafid 2000).

\section{Growth of the Tidsi anticline}

The Mesozoic age of the growth of the Tidsi structure is based on (1) an unconformity separating Triassic from Portlandian (i.e., uppermost Jurassic) strata, (2) a significant increase in the thickness of the Lower Cretaceous from the eastern to the western side of the Tidsi anticline
Fig. 9 Geological map of the NW part of the Imi-n-Tanout wedge showing synsedimentary folds sealed by Upper Cretaceous rocks. Simplified from sheet Tamnar of the 1:100,000 geological map of Morocco

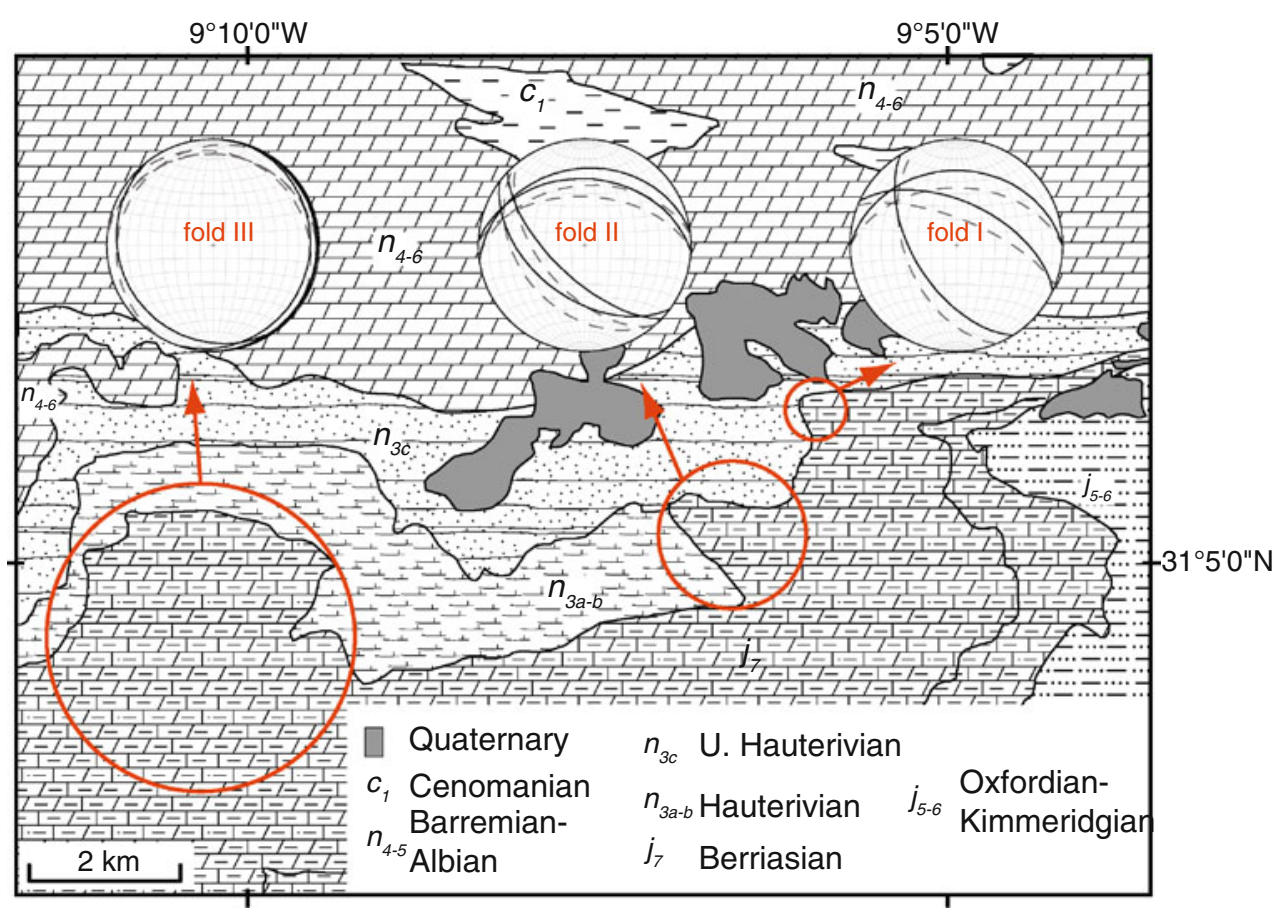




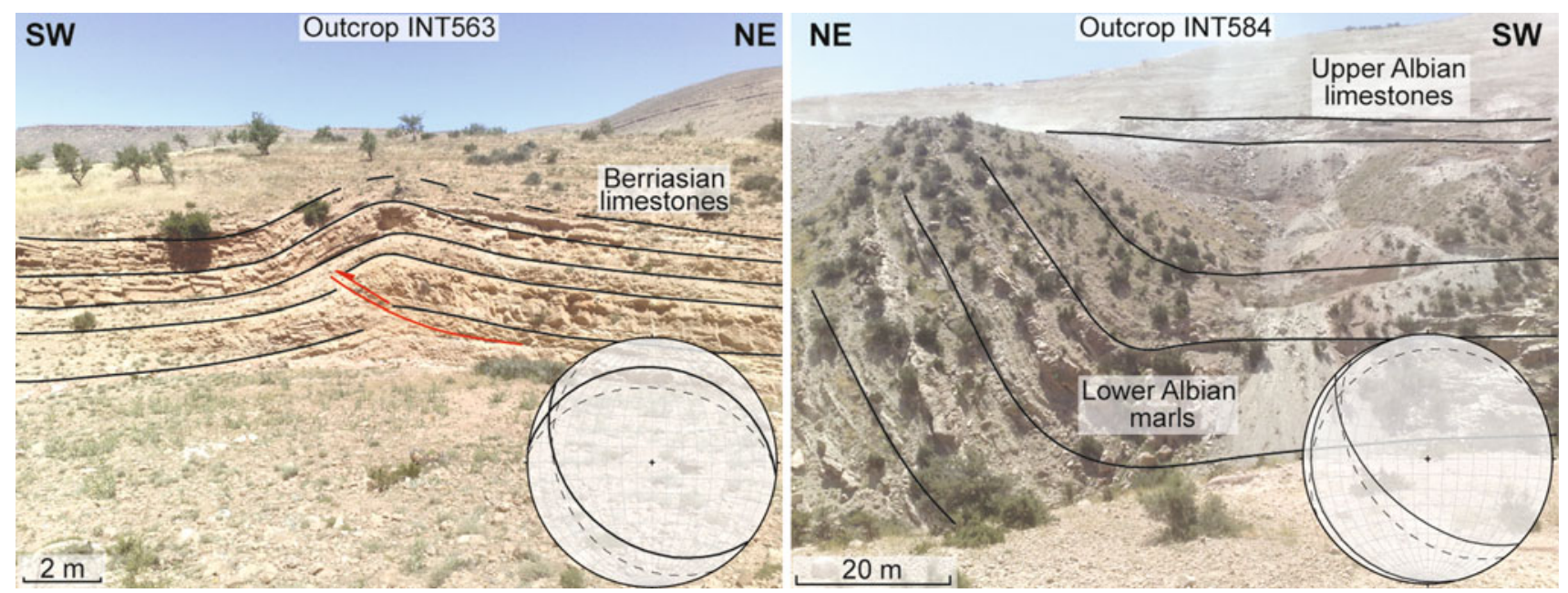

Fig. 10 Outcrop-scale syn-sedimentary structures in the Middle Jurassic to Lower Cretaceous formations of the INT wedge

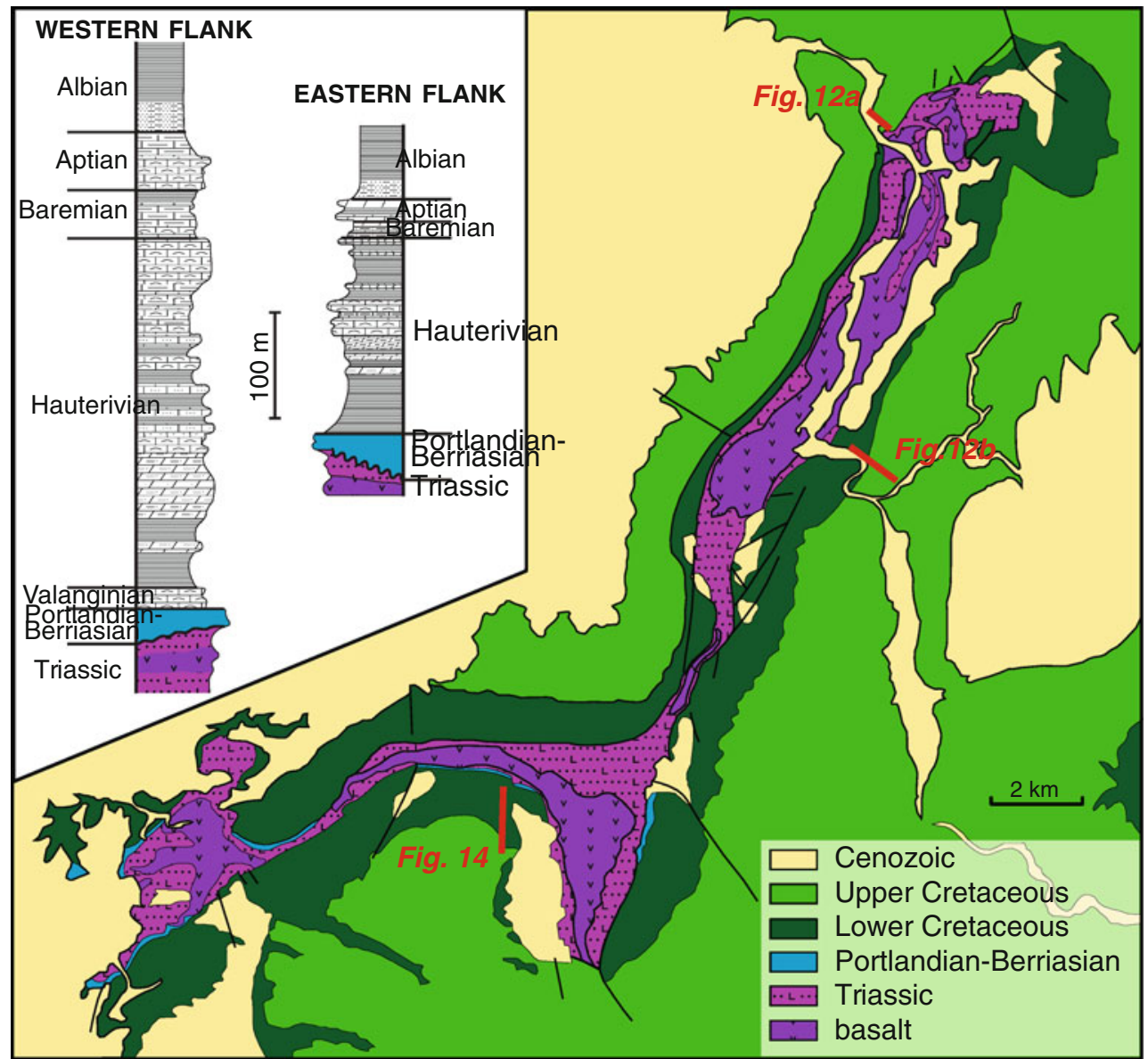

Fig. 11 Map of the Tidsi anticline. Representative stratigraphic columns for the western and eastern sides of the structure are shown in the insets, after the 1:100,000 geological map of Morocco (Tamnar sheet)

(Fig. 11) and, (3) the sedimentary wedges exposed along the N-S trending flanks of the structures (Fig. 12).

The unconformity at the base of the Portlandian is well exposed along the foot of the relief forming the eastern side of the Tidsi structure (Fig. 12) and is formed by an erosional surface separating sub-vertical Triassic layers from Lower Cretaceous strata, which dip by $40-50^{\circ}$ to the E. The base of Lower Cretaceous layers is generally parallel to the unconformity surface, showing that the relief formed during pre-Late Jurassic folding had been 


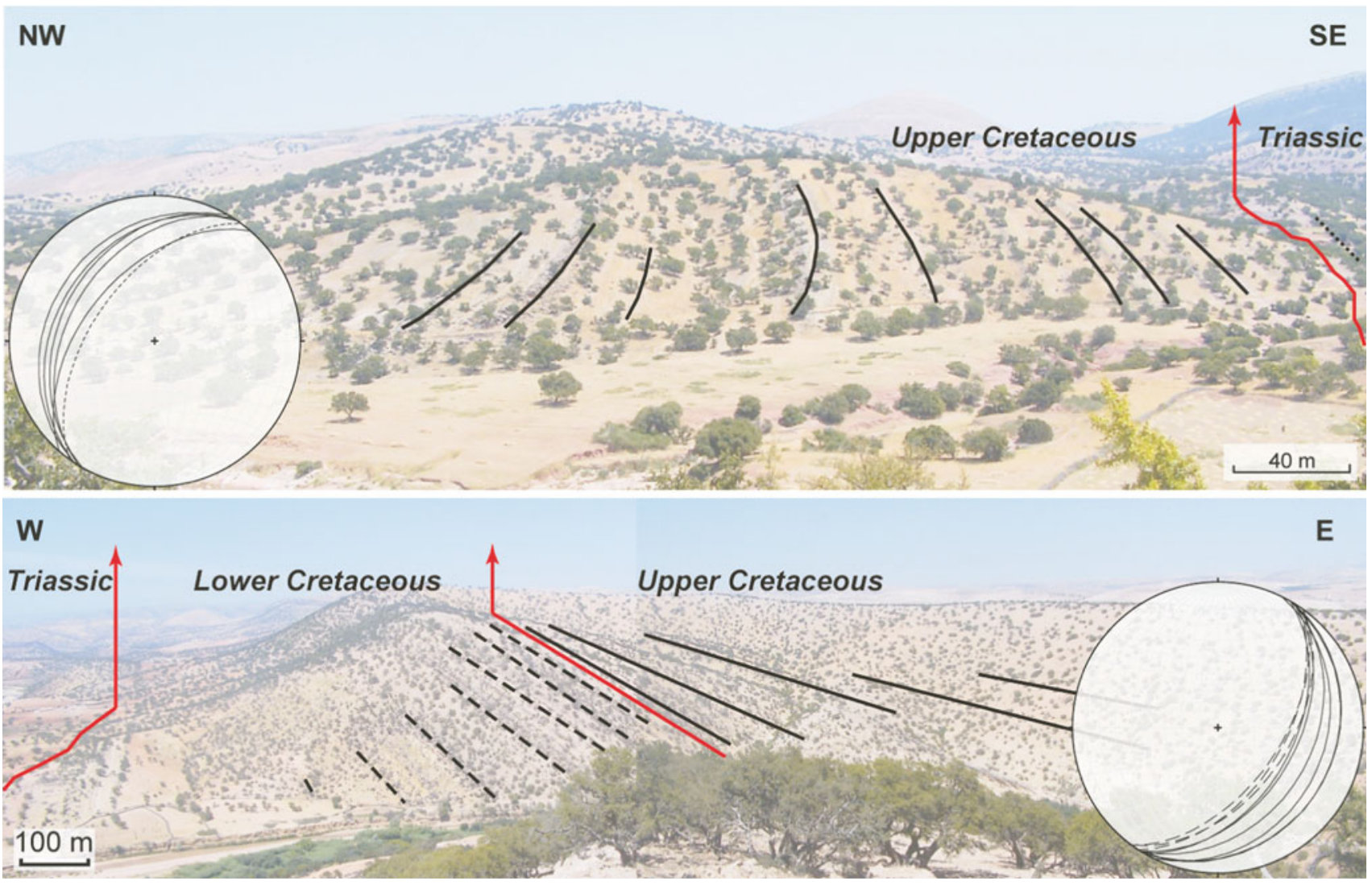

Fig. 12 Syn-sedimentary wedges along the N-S trending flanks of the Tidsi anticline. See Fig. 11 for location

effectively peneplained and that the entire area experienced regional subsidence during the Early Cretaceous (Fig. 13a). Lower Cretaceous rocks, however, are thinner in the $\mathrm{E}$ than in the $\mathrm{W}$ of the Tidsi structure recording the beginning of differential vertical movements possibly related to the onset of west-vergent folding-thrusting. A re-activation of a syn-rift normal fault is unlikely because the main extensional fault in the area is located several kilometers to the $\mathrm{E}$ of the Tidsi structure and no significant inversion can be identified in seimic sections [see Fig. 14 in Hafid (2000)].

Notwithstanding the poor constraints on the initial stages of the Tidsi structure, anticlinal folding was ongoing in the Late Cretaceous causing the formation of the wellknown sedimentary wedges seen along sections perpendicular to the fold (Fig. 12). The growth of the Tidsi anticline took place during generalized, long wavelength subsidence (Fig. 13b), affecting the entire region $\mathrm{W}$ of the MAM and allowing for continuous sedimentation.

\section{Tectonics during Tidsi folding}

Notwithstanding the possible role of diapirism in controlling the growth of the Tidsi anticline, other structures observed in the area document the co-existence of tectonic deformations hitherto neglected.

The nicest structures are visible along a $>1-\mathrm{km}$-long cliff in the southern part of the Tidsi anticline where Triassic to Aptian sediments crop out (Fig. 14). Two wedges formed by Lower Cretaceous rocks are visible, opening

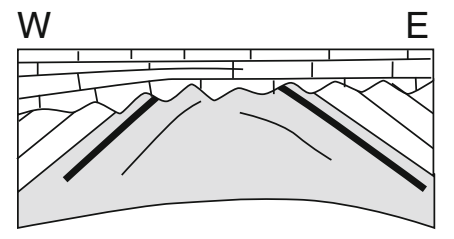

(a) Early Cretaceous

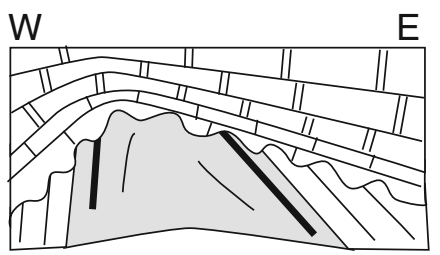

(b) Late Cretaceous

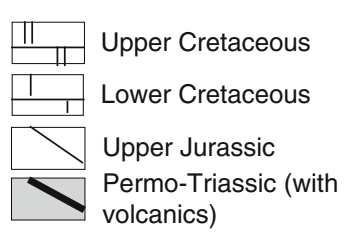
volcanics)

Fig. 13 Evolutionary scheme of the Tidsi anticline in pre-Alpine times 
toward the south and bounded on the southern side by steeper layers. Strata geometry points to a NNE-ward vergence of the structure (Fig. 14). Aptian strata in the uppermost part of the outcrop are sub-horizontal thereby documenting the pre-Aptian age of deformation. The tectonic nature of these structures is not only suggested by their overall geometry but is proven by their vergence toward the core of the Tidsi anticline, which is incompatible with a halokinetic origin.

\section{The Middle Jurassic to Early Cretaceous tectonic evolution of central Western Morocco}

Kinematics and tectonics of a section from the MAM to the Essaouira basin

\section{Data and methods}

To provide a kinematic frame for the evolution of western Morocco, we construct a $\sim 100-\mathrm{km}-$ long, E-W trending section from the MAM in the $\mathrm{E}$ to the coastal domains of the Essaouira-Agadir basin in the $\mathrm{W}$ depicting the situation at the end of the Early Cretaceous before the Cenomanian transgression. We then retrodeform the section compensating for vertical movements from the end of the Early
Cretaceous to the Early Jurassic, which is the approximate age of the opening of the Central Atlantic. The section has a composite character and includes information from the northern and southern side of the High Atlas.

The geometry of Middle Jurassic to Lower Cretaceous sediments in the western part of the section is obtained from the literature data (Zühlke et al. 2004; Piqué et al. 1998; Bouatmani et al. 2007; Le Roy and Piqué 2001; Hafid 2000). Sediment thicknesses were not corrected for compaction during retrodeformation. Vertical movements in the MAM have been derived from the $\mathrm{t}-\mathrm{T}$ paths obtained by Ghorbal (2009) for samples from the northern and southern foothills of the High Atlas (e.g., Fig. 2), translated into depths adopting a constant gradient of $25^{\circ} \mathrm{C} / \mathrm{km}$.

\section{Kinematic evolution}

The upper panel of Fig. 15 shows a simplified geological transect along the western High Atlas toward the end of the Early Cretaceous. The section is characterized by an up to 6-km-thick succession of Triassic to Lower Cretaceous sediments thinning toward the $\mathrm{E}$ and essentially pinchingout against the MAM. The post-rift (post-Toarcian) part of the succession which accumulated following the end of normal faulting reaches thicknesses of $>3 \mathrm{~km}$. No significant normal fault is present at the scale of the transect.

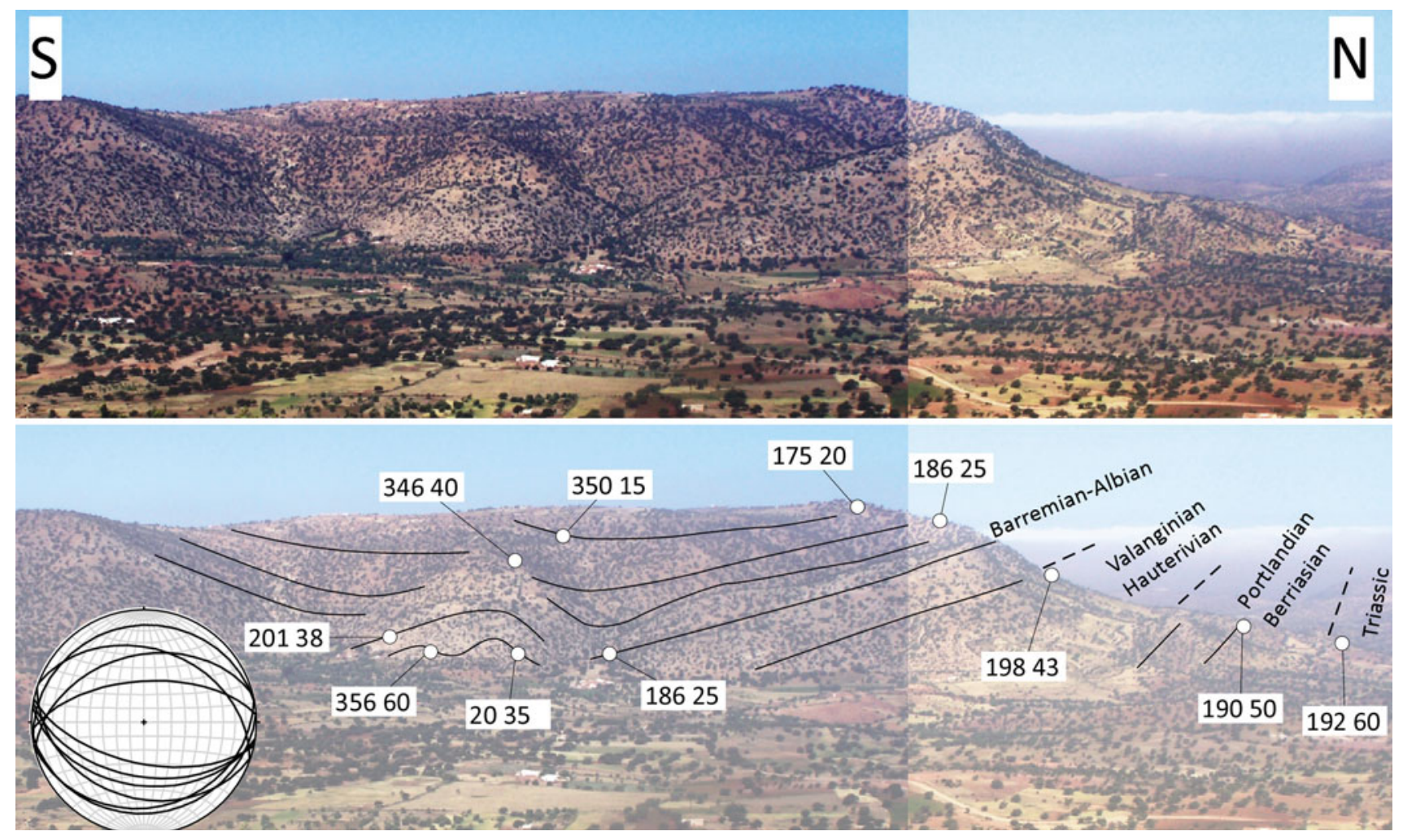

Fig. 14 Line-drawing of the structures exposed in the southern part of the Tidsi anticline (see Fig. 11) for the position. The cliff is ca. $200 \mathrm{~m}$ high 

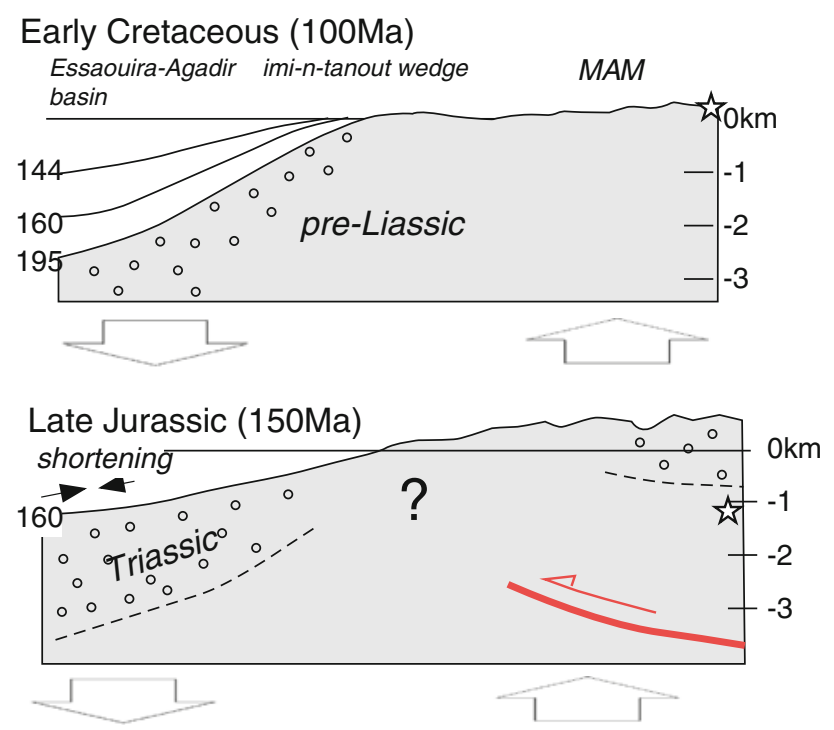

Middle Jurassic (170Ma)

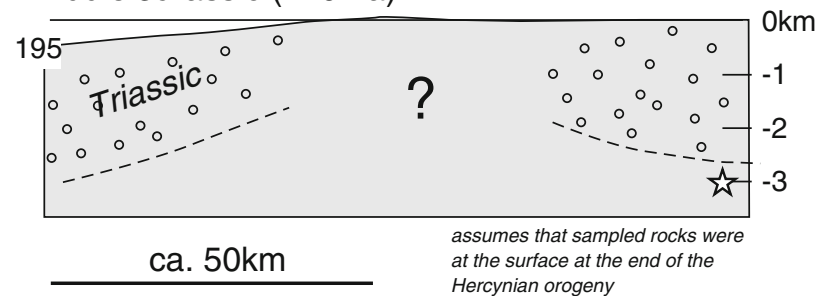

Fig. 15 Middle Jurassic to Early Cretaceous vertical movements along a section from the Essaouira basin in the W to the MAM in the E. The section trends roughly $\mathrm{E}-\mathrm{W}$ and includes information from both sides of the High Atlas

The eastern part of the section was probably occupied by a peneplain close to sea level resulting from the erosion of the mountain belt which must have formed during earlier exhumation stages.

The oldest snapshot of our kinematic scheme (at $170 \mathrm{Ma}$ ) depicts the situation at the end of the Liassic shortly after the cessation of normal faulting in the Essaouira basin. In the W, a ca. 3-km-thick succession was present, which was pinching-out toward the E. Toward the $\mathrm{W}$, the Triassic wedge is interpreted to be controlled by a major, E-dipping listric fault presently covered by younger sediments (Medina 1995). In the $E$, the presently cropping out basement rocks of the MAM were at the end of the Liassic at depths of ca. $3 \mathrm{~km}$. If the assumption is justified that they were close to the surface at the end of the Hercynian orogeny then one must envisage the presence of 2-3 km of sediments which were removed prior to the Late Cretaceous.

Starting from 170 to $150 \mathrm{Ma}$, the rocks of the MAM began moving upward, thereby probably generating a relief which was the source area for the thick terrigenous successions deposited in the Moroccan offshore (Price 1981; Le Roy and Piqué 2001). This upward movement was coeval with increased subsidence in the western parts of the section, and it is during this time frame that syn-sedimentary contractional structures developed, which have been described in chapter 4. Coeval subsidence in the W and exhumation in the E ended probably toward the end of the Early Cretaceous, beginning of the Late Cretaceous when the entire region, as well as North Africa, was covered by Cenomanian marine sediments (e.g., Luning et al. 2004) and followed by generalized subsidence.

The profiles of Fig. 15 show that no major fault existed during Middle Jurassic to Early Cretaceous times accommodating the differential movement between the subsiding Essaouira-Agadir basin and the exhuming MAM. These movements, on the contrary, were associated with generalized westward tilting of the pre- and syn-rift successions. The timing and geometry of such tilting is documented in the Imi-n-Tanout wedge. Because of the excessive subsidence and, more importantly, exhumation, this tilting cannot be the expression of post-rift thermal subsidence.

Our, admittedly speculative, working hypothesis is that the excessive subsidence in the Essaouira basin and exhumation in the MAM were caused by roughly E-W trending shortening active during Middle Jurassic to Early Cretaceous times. A contractional regime is compatible with the widespread occurrence of syn-sedimentary contractional structure in Upper Jurassic to Lower Cretaceous successions. The E-W shortening could be accommodated either by deep W-vergent thrusting in the MAM or by folding, or a combination of the two (e.g., Cloetingh and Burov 2011).

\section{Extrapolation to surrounding areas}

The coexistence of subsidence in the $\mathrm{W}$ and exhumation in the $\mathrm{E}$, as well as the occurrence of syn-sedimentary structures documenting shortening during Jurassic to Lower Cretaceous times, are not confined to the western High Atlas but are is observed also to the North and to the South of the chain.

\section{The region $N$ of the High Atlas}

The exhumation we have reported in the MAM can be traced to the $\mathrm{N}$ of the High Atlas. Indeed, Mesozoic ages and $\mathrm{t}-\mathrm{T}$ paths comparable to the ones discussed above have been obtained from rocks from the Jebilet Hills $\mathrm{N}$ of Marrakech to the Rabat area (e.g., Ghorbal et al. 2008; Saddiqi et al. 2009; Barbero et al. 2011). Subsidence along the Central Atlantic margin to the $\mathrm{N}$ of the EssaouiraAgadir basin has been quantified and modeled by Gouiza et al. (2010). The curves these authors produced document persisting post-rift subsidence compatible with what we have shown for the Eassouira-Agadir basin. Gouiza et al. 
(2010) could only fit the data from the best constrained part of the section by envisaging intense sub-crustal thinning during Middle Jurassic times.

Jurassic contractional structures similar to those described above in the Essaouira basin are observed in the Abda basin, located to the $\mathrm{N}$ of the High Atlas. Here, seismic data document gentle folded Triassic to Middle Jurassic layers sealed by Upper Jurassic(?)-Cretaceous strata (Echarfaoui et al. 2002).

\section{The regions to the S of the High Atlas}

The zone of exhumation inferred from the MAM continued also to the S of the High Atlas. Low-T geochronology results from the westernmost part of the Anti-Atlas have very recently become available (Ruiz et al. 2011). According to this study, rocks of the area have experienced continuous exhumation (in the order of 3-4 km) during Triassic to Early Cretaceous time followed by more limited subsidence and exhumation during Tertiary times. This pattern is not substantially different from that documented from the Meseta and the MAM. These results are compatible with previous, very limited geochronology data from Malusà et al. (2007) and illite maturity studies (Ruiz et al. 2008) and by maturity and geochronology work in the Tindouf basin (Zühlke et al. 2010), south of the Anti-Atlas. In both cases, rocks were found to be too mature/hot with respect to their geological evolution and present position.

Subsidence patterns have been analyzed by Gouiza (2011) in the Tarfaya basin which lies to the W of the AntiAtlas region. Similarly to what is shown above, these curves show strong subsidence persisting through Middle to Late Jurassic times, that is, coeval with the subsidence reported for the Essaouira-Agadir basin.

\section{The regions to the $E$ of the High Atlas}

At the regional scale, the vertical movements and deformations documented in Morocco are partly coeval with the Austrian orogeny (Barremian to Aptian), which resulted in a W-E directed shortening episode well-documented in the entire West Sahara domain in Algeria, Tunisia and Libya (Acheche et al. 2001; Mitra and Leslie 2003; Underdown and Redfern 2008). The origin of this tectonic stage remains enigmatic, a possible explanation could be the change in the rate and direction of opening of the Atlantic following the separation between West Africa and South America and the initiation of the South Atlantic drifting (Mitra and Leslie 2003). Shortening resulted in N-S oriented folding, reactivation and uplift of the already existent fault blocks (Mitra and Leslie 2003), and the Austrian unconformity which truncated the Barremian-Neocomian deposits in the region.

\section{Conclusions}

The Middle Jurassic to Early Cretaceous time interval is of particular interest for the evolution of Morocco and, indirectly, also for surrounding regions because of the coexistence of subsidence and exhumation along an E-W trending profile. The upward movements have allowed for the erosion of substantial amount of rocks, part of which was then transported toward the Central Atlantic Ocean and deposited on the Moroccan passive continental margin (e.g., Lancelot and Winterer 1976; von Rad and Sarti 1986; Price 1981).

A significant part of these movements, ca. $50 \%$ for the subsiding domain and $>70 \%$ for the one experiencing exhumation, is incompatible with processes generally expected to take place during the post-rift of continental margins, namely thermal subsidence. Even more complex mechanisms indirectly related to rifted margin formation, such shoulder uplift and secondary convection cells are unable to explain the observed movements.

As an alternative, we tentatively propose a scenario in which vertical movements are driven roughly $\mathrm{E}-\mathrm{W}$ trending shortening superimposed on the thermal subsidence of the margin. This picture is compatible with the widespread occurrence of contractional structures developed in Jurassic to Early Cretaceous times in the western parts of the High Atlas and surrounding areas.

Indeed, our findings are not unique, and larger-thanexpected upward movements have been documented in other passive margins such as Brazil (Bonow et al. 2009), the Dhofar margin (e.g., Bache et al. 2011 and references therein) and Antarctica (Storti et al. 2008).

Acknowledgments A significant part of the work at the base of this contribution has been conducted by Bachelor and Master students (K. Brautigam, J. Klaver, D. Fernandez-Blanco) of the VU University of Amsterdam during the last few years. N. Froitzheim (Bonn) is thanked for sharing his publications and knowledge. M. Hafid is thanked for support and discussions. The Editor of the International Journal of Earth Sciences and the two reviewers of the journal are thanked for their constructive criticisms.

Open Access This article is distributed under the terms of the Creative Commons Attribution License which permits any use, distribution, and reproduction in any medium, provided the original author(s) and the source are credited.

\section{References}

Acheche M, M'rabet A, Ghariani H, Ouahchi A, Montgomery S (2001) Ghadames basin, southern Tunisia: a reappraisal of Triassic reservoirs and future prospectivity. AAPG Bull 85:765-780

Amrhar M (1995) Évolution structural du Haut Atlas occidental dans le cadre de l'overture de l'Atlantique central et de la collision 
Europe-Afrique: Structure, instabilité tectonique et magmatisme. $\mathrm{PhD}$ Thesis, Cadi Ayad University, Marrakech, Morocco

Arboleya ML, Teixell A, Charroud M, Julivert M (2004) A structural transect through the High Atlas and Middle Atlas, Morocco. J Afr Earth Sci 39:319-327

Bache F, Leroy S, Baurion C, Robinet J, Gorini C, Lucazeau F, Razin P, d'Acremont E, El-Touibi K (2011) Post-rift uplift of the Dhofar margin (Gulf of Aden). Terra Nova 23:11-18

Balestrieri ML, Moratti G, Bigazzi G, Algouti A (2009) Neogene exhumation of the Marrakech High Atlas (Morocco) recorded by apatite fission-track analysis. Terra Nova 21:75-82

Barbero L, Jabaloy A, Gómez-Ortiz D, Pérez-Peña JV, RodríguezPeces MJ, Tejero R, Estupiñán J, Azdimousa A, Vázquez M, Asebriy L (2011) Evidence for surface uplift of the Atlas Mountains and the surrounding peripheral plateaux: combining fission-track results and geomorphic indicators in the western Moroccan Meseta (coastal Variscan Paleozoic basement). Tectonophysics 502:90-104

Baudon C, Fabuel-Perez I, Refern J (2009) Structural style and evolution of a Late Triassic rift basin in the Central High Atlas, Morocco: controls on sediment deposition. Geol J 44:677-691

Bertotti G, Gouiza M, Foeken J, Andriessen P (2010) Late JurassicEarly Cretaceous tectonics and exhumation onshore Morocco: Implication for terrigenous sands reservoirs in the offshore of NW Africa. Search and Discovery, article \#50353@2010, AAPG Annual Convention and Exhibition, 11-14 April 2010

Bonow JM, Japsen P, Green PF, Cobbold P, Pedreira AJ, Lilletveit R, Chiossi D (2009) Post-rift landscape development of north-east Brazil. Bull Geol Surv Den Greenl 17:81-84

Bouaouda MS (2004) Le Jurassique du basin d'Agadir (Maroc): intérpretation paléogéographique. Rev Paléobiol 23:67-80

Bouatmani R, Chakor Alami A, Medina F (2007) Subsidence, évolution thermique et maturation des hydrocarbures dans le bassin d'Essaouira (Maroc): apport de la modélisation. Bull de l'Institut Scientifique, Rabat 29:15-36

Burkhard M, Caritg S, Helg U, Robert C, Charrue C, Soulaimani A (2006) Tectonics of the anti Atlas of Morocco. C R Geosci $338: 11-24$

Burov E, Cloetingh S (1997) Erosion and rift dynamics: new thermomechanical aspects of post-rift evolution of extensional basins. Earth Planet Sci Lett 150:7-26

Cerrina-Feroni A, Ellero A, Malusà M, Musumeci G, Ottria G, Polino R, Leoni L (2010) Transpressional tectonics and nappe stacking along the Southern Variscan Front of Morocco. Int J Earth Sci 99:1111-1122

Chalouan A, Michard A, Feinberg H, Montigny R, Saddiqi O (2001) The Rif mountain building (Morocco): a new tectonic scenario. Bull Soc Geol France 172:603-616

Cloetingh S, Burov E (2011) Lithospheric folding and sedimentary basin evolution: a review and analysis of formation mechanisms. Basin Res 23:257-290

Davison I (2005) Central Atlantic margin basins of North West Africa: geology and hydrocarbon potential. J. Afr Earth Sci 43:254-274

Echarfaoui H, Hafid M, Ait Salem A, Abderahmane AF (2002) Analyse sismo-stratigraphique du basin d'Abda (Maroc occidental), examples de structures inverses pendant le rifting atlantique. C R Geosci 334:371-377

Ellouz N, Patriat M, Gauilier JM, Boutmani R, Sabounji S (2003) From rifting to Alpine inversion: Mesozoic and Cenozoic subsidence history of some Moroccan basins. Sediment Geol 156:185-212

Frizon de Lamotte D, Saint Bézard B, Bracene R, Mercier E (2000) The two main steps of Artlas building and geodynamics of the western Mediterranean. Tectonics 19:740-771. doi:10.1029/2000T C900003
Ghorbal B (2009) Mesozoic to Quaternary thermo-tectonic evolution of Morocco (NW Africa). PhD thesis, VU University Amsterdam, p 231

Ghorbal B, Bertotti G, Foeken J, Andriessen P (2008) Unexpected Jurassic to Neogene vertical movements in "stable" parts of NW Africa revealed by low temperature geochronology. Terra Nova 20:353-363. doi:10.1111/j.1365-3121.2008.00828.x

Gouiza M (2011) Mesozoic source-to-sink systems in NW Africa: Geology of vertical movements during the birth and growth of the Moroccan rifted margin. PhD Thesis, VU University Amsterdam, p 170

Gouiza M, Huismans RS, Bertotti G (2009) Differential thinning and small-scale convection during formation of non-volcanic conjugate Morocco-Nova Scotia passive margin: Insights from thermo-mechanical modelling. American Geophysical Union, Fall meeting 2009, article \#T31C-1858

Gouiza M, Bertotti G, Hafid M, Cloetingh S (2010) Kinematic and thermal evolution of the Moroccan continental margin: Doukkala-HighAtlas transect. Tectonics 29:TC5008. doi:10129/ 2009TC002464

Guimera J, Arboleya ML, Teixell A (2011) Structural control on present-day topography of a basement massif: the central and eastern Anti-Atlas (Morocco). Geol Acta 9:55-65

Hafid M (2000) Triassic-early Liassic extensional systems and their tertiary inversion. Essaouira Basin Morocco Marine Petrol Geol 17:409-429

Hafid M, Zizi M, Bally AW, Ait Salem A (2006) Structural styles of the western onshore and offshore termination of the High Atlas, Morocco. C R Geosci 338:50-64

Hafid M, Tari G, Bouhadioui D, El Moussaid I, Echarfaoui H, Aït Salem A, Nahim M, Dakki M (2008) Atlantic basins. In: Michard A, Saddiqi O, Chalouan A, Frizon de Lamotte D (eds) Continental evolution: the geology of Morocco (Lecture notes in earth sciences), vol 116. pp 302-330

Hoepffner C, Soulaimani A, Piqué A (2005) The Moroccan hercynides. J Afr Earth Sci 43:144-165

Japsen P, Bonow JM, Green PF, Chalmers JA, Lidmar-Bergström K (2009) Formation, uplift and destruction of planation surfaces at passive continental margins. Earth Surf Proc Land 34:683-699

Kooi H (1991) Tectonic modelling of extensional basins: the role of lithospheric flexure, intraplate stress and relative sea-level change. PhD thesis, VU University Amsterdam

Kooi H, Cloetingh S, Burrus J (1992) Lithospheric necking and regional isostasy at extensional basins 1 . Subsidence and gravity modeling with an application to the Gulf of Lions Margin (SE (France). J Geophys Res 97:17553-17571

Labails C, Olivet JL, Aslanian D, Woest RR (2010) An alternative early opening scenario for the Central Atlantic Ocean. Earth Plaent Sci Lett 297:355-368

Lancelot Y, Winterer EL (1976) Evolution of the Moroccan oceanic basin and adjacent continental margin-a synthesis. Initial reports Deep Sea Drilling Project, vol 50, pp 801-821

Laville E, Pique A, Amrhar M, Charroud M (2004) A restatement of the Mesozoic Atlasic rifting (Morocco). J Afr Earth Sci 38:145-153

Le Roy P, Piqué A (2001) Triassic-Liassic Western Moroccan syn-rift basins in relation to the Central Atlantic opening. Marine Geol 172:359-381

Lucazeau F et al (2008) Persistent thermal activity at the Eastern Gulf of Aden after continental break-up. Nat Geosci 1:854-858. doi: 10.1038/ngeo359

Luning S, Kolonic S, Belhadj M (2004) Integrated depositional model for the Cenomanian-Turonian organic-rich strata in North Africa. Earth Sci Rev 64:51-117

Malusà MG, Polino R, Cerrine-Feroni A, Ellero A, Ottria G, Baidder L, Musumeci G (2007) Post-Variscan tectonics in eastern AntiAtlas (Moroccco). Terra Nova 19:481-489 
McKenzie D (1978) Some remarks on the origin of sedimentary basins. Earth Planet Sci Lett 40:25-32

Medina F (1995) Syn- and post-rift evolution of the El JadidaAgadir basin (Morocco): constraints for the rifting models of the Central Atlantic. Can J Earth Sci 32:1273-1291

Michard A (1976) Elément de Géologie Marocaine. Notes et Mémoires du Service Géologique \#252, Rabat, Morocco

Michard A, Hoepffner C, Soulaimani A, Baidder L (2008) The Variscan belt. In: Michard A, Saddiqi O, Chalouan A, frizon de Lamotte D (eds) Continental evolution: the geology of Morocco (Lecture notes in earth sciences) Berlin, pp 65-132

Missenard Y, Saddiqi O, Barbarand J, Ruiz GMH, El Haimer F, Leturmy P, Frizon de Lamotte D (2008) Cenozoic thermally induced denudation in the Marrakech High atlas, Morocco: insight from fission tracks. Terra Nova 20:221-228

Mitra S, Leslie W (2003) Three-dimensional structural model of the Rhourde el Baguel field, Algeria. AAPG Bull 87:231-250

Piqué A, Le Roy P, Amrhar M (1998) Transtensive synsedimentary tectonics associated with ocean opening: the Essaouira-Agadir segment of the Moroccan Atlantic margin. J Geol Soc Lond 155:913-928

Price L (1981) Provenance of the Jurassic-Cretaceous flysch. Deep Sea Drilling Project sites 370 and 416, Initial Reports Deep Sea Drilling Project, vol 50, pp 751-757

Ruiz GMH, Helg U, Negro F, Adatte T, Burkhard M (2008) Illite crystallinity patterns in the Ant-Atlas of Morocco. Swiss J Geosci 101:387-395

Ruiz GMH, Sebti S, Negro F, Saddiqi O, Frizon de Lamotte D, Stöckli D, Foeken J, Stuart F, Barbarand J, Schaer JP (2011) From central Atlantic continental rift to Neogene upliftwestern Anti-Atlas, Morocco. Terra Nova 23:35-41

Saddiqi O, El Haimer FZ, Michard A, Barbarand J, Ruiz GMH, Mansour EM, Leturmy P, Frizon de Lamotte D (2009) Apatite fission-track analyses on basement granites from south-western Meseta, Morocco: paleogeographic implications and interpretation of AFT discrepancies. Tectonophysics 475:29-37. doi: 10.1016/j.tecto.2009.01.007
Sahabi M, Daniel A, Olivet JL (2004) Un nouveau point de départ pour l'histoire de l'Atlantique central. C R Geosci 336:1041-1052. doi:10.1016/j.crte.2004.03.017

Steckler MS (1985) Uplift and extension at the Gulf of Suez: indications of induced mantle convection. Nature 317:135-139

Stets J (1992) Mid-Jurassic events in the High Atlas. Geol Rundsch 81:69-84

Stets J, Wurster P (1982) Atlas and Atlantic-structural relations. In: von Rad U, Hinz K, Sarthein M, Seibold E (eds) Geology of the Northwest Africa continental margin. Springer, Berlin, pp 69-85

Storti F, Balestrieri ML, Balsamo F, Rossetti F (2008) Structural and thermochronological constraints to the evolution of the West Antarctic rift system in Central Victoria Land. Tectonics 27:4012. doi:10.1029/2006TC002066

Teixell A, Arboleya ML, Julivert M, Charroud M (2003) Tectonic shortening and topography in the Central High Atlas (Morocco). Tectonics 22:1051. doi:10.1029/2002TC001460

Underdown R, Redfern J (2008) Petroleum generation and migration in the ghadames basin, north africa: a two-dimensional basinmodeling study. AAPG Bull 92:53

Verati C, Rapaille C, Feraud G, Marzoli A, Bertrand H, Youbi N (2007) 40Ar/39Ar ages and duration of the Central Atlantic Magmatic Province volcanism in Morocco and Portugal and its relation to the Triassic-Jurassic boundary. Palaeogeogr Palaeoclimatol Palaeoecol 244:308-325. doi:10.1016/j.palaeo.2006.06.033

von Rad U, Sarti M (1986) Early Cretaceous "events" in the evolution of the eastern and western North Atlantic continental margin. Geol Rundsch 75:139-158

Zühlke R, Bouaouda MS, Ouajhain B, Bechstädt T, Leinfelder R (2004) Quantitative Meso-Cenozoic development of the eastern Central Atlantic continental shelf, western High Atlas, Morocco. Marine Petrol Geol 21:225-276

Zühlke R, Lewandowski E, Jäger H, Bechstädt T, Rahmani A, Wirth B, Bökman F (2010) Integrated basin and HC systems model, Silurian-Carboniferous, Southern Algeria. Search and Discovery, article \#50344 